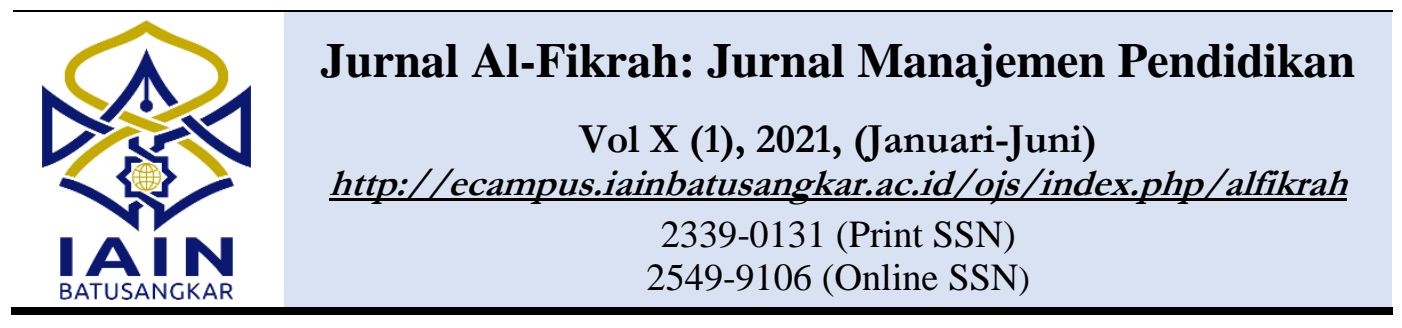

Literacy-Based ndependent Learning Planning on Science Learning at SMP Negeri 12 Sijunjung

\title{
Perencanaan Merdeka Belajar Berbasis Literasi Pada Pembeajaran PA di SMP Negeri 12 Sijunjung
}

Received:27-05-2021; Revised:15-06-2021; Accepted:17-06-2021

\author{
Yenny Septi ${ }^{\left.i^{*}\right)}$, Sirajul Munir ${ }^{2}$, M. Haviz ${ }^{3}$ \\ Institut Agama slam Negeri (IAIN) Batusangkar \\ Korespondensi: Jl. Sudirman No.137 Kuburajo, Limakaum, Batusangkar, Sumataera Barat \\ E-mail:yenny_septi@iainbatusangkar.ac.id, sirajulmunir@iainbatusangkar.ac.id, \\ mhaviz@iainbatusangkar.ac.id \\ *) Corresponding Author
}

\begin{abstract}
120
Abstract: Literacy-based ndependent learning planning s mportant to be applied $n$ the science learning process. The principal as the manager of SMP Negeri 12 Sijunjung was very enthusiastic $n$ welcoming the concept of ndependent learning. Teachers and observers of education at SMP Negeri 12 Sijunjung hope that the concept of ndependent learning that will be applied by the school will bring positive changes to the development of the quality of education at that school because this will help provide students with the skills needed $n$ the 21st century. The results showed that, planning $n$ the literacy-based ndependent learning program n science learning at SMP Negeri 12 Sijunjung was conducted by bolding deliberations with various related elements. Planning lessons was carried out $n$ the classroom, and outside, planning $n$ learning was cnducted by carrying out a literacy movement that has 2 goals, namely general goals and specific goals. Planning constraints $n$ the literacy-based ndependent learning program $n$ science learning at SMP Negeri 12 Sijunjung consists of 3 obstacles, namely: 1). Lack of human resources who can understand literacy programs properly and correctly; 2) time for literacy activities at school; and 3) the school library s only limited to the school library, and the library collection only provides school books, very few other additional books.
\end{abstract}

Keyword: ndependent Learning Planning, Literacy-Based, Science Learning

Abstrak-Perencanaan pembelajaran mandiri berbasis literasi penting untuk diterapkan dalam proses pembelajaran PA. Kepala sekolah selaku pengelola SMP Negeri 12 Sijunjung sangat antusias menyambut konsep belajar mandiri. Guru dan pemerhati pendidikan di SMP Negeri 12 Sijunjung berharap konsep belajar mandiri 
yang akan diterapkan sekolah akan membawa perubahan positif bagi perkembangan mutu pendidikan di sekolah, karena akan membantu membekali siswa dengan keterampilan yang dibutuhkan dalam pembelajaran. abad ke-21. Hasil penelitian menunjukkan bahwa, perencanaan program pembelajaran mandiri berbasis literasi pada pembelajaran PA di SMP Negeri 12 Sijunjung dengan mengadakan musyawarah dengan berbagai unsur terkait. Merencanakan pelajaran yang akan dilaksanakan di dalam kelas dan di luar kelas. Perencanaan dalam pembelajaran dengan melakukan gerakan literasi yang memiliki 2 tujuan yaitu tujuan umum dan tujuan khusus. Kendala perencanaan dalam program pembelajaran mandiri berbasis literasi pada pembelajaran PA di SMP Negeri 12 Sijunjung terdiri dari 3 kendala, yaitu: 1). Kurangnya SDM yang dapat memahami program literasi dengan baik dan benar, 2). waktu untuk kegiatan literasi di sekolah dan 3). perpustakaan sekolah hanya sebatas perpustakaan sekolah, dan koleksi perpustakaan hanya menyediakan buku sekolah, sangat sedikit buku tambahan lainnya.

Kata Kunci: Perencanaan Pembelajaran Mandiri, Berbasis Literasi, Pembelajaran Sains

\section{PENDAHULUAN}

$\mathrm{P}$ rogram merdeka belajar yang tengah hangat dalam kurun waktu belakangan ni hakikatnya merupakan salah satu upaya untuk menanamkan pemahaman pada segenap pengambil dan pelaksana kebijakan pendidikan untuk melihat bahwa nilai atau hasil belajar bukanlah penentu kompetensi seseorang. Akreditasi bukan pula patokan atau menjadi tolak ukur kemampuan sebuah lembaga dalam mencetak lulusan yang berkualitas. Alhasil, perlu ada kebijakan yang tepat untuk mengukur kapabilitas lulusan.

Memang, hal ni tidak biasa luput dari sebagian kekurangan (tujuan) masyarakat atas kebijakan yang berlaku. Sebagian masyarakat saat ni beranggapan bahwa kebijakan tersebut berlangsung atas banyaknya siswa yang terlalu santai dalam belajar karena tidak lagi memikirkan Ujian Nasional (UN) yang sebetulnya tu adalah sebagai tolak ukur kemampuan kompetensi secara nasional yang materi soal-soalnya bersesuaian dengan kurikulum yang berlaku pada tiap-tiap zamannya. Hal ni tentu seiring dengan kemunculan masyasrakat 5.0 yang merupakan mplikasi dari perkembangan pesat revolusi ndustri 4.0 yang mengubah tatanan ndustri konvensional ke digital secara eksponensial. Medan pendidikan akan berada dalam kumparannya, serta menyesuaikan dan disesuaikan (Houtman, 2020: 39).

Fenomena pendidikan merdeka belajar merupakan respon terhadap kebutuhan sistem pendidikan pada era Revolusi ndustri 4.0. Di era Revolusi ndustri 4.0 kebutuhan utama yang ngin dicapai dalam sistem pendidikan atau lebih khusus dalam metode pembelajaran yaitu siswa atau peserta didik yaitu penguasaan terhadap literasi baru. Literasi baru tersebut yaitu. Pertama, literasi data. Kedua, literasi teknologi. Terakbir, literasi manusia (Yamin \& Syahrir, 2020: 126).

Fenomena lain yang terjadi 
terhadap konsep merdeka belajar adalah sebagaimana yang telah ditulis oleh Nofri Hendri, yaitu kemerdekaan adalah satu kata yang tidak asing lagi yang sering dimaknai dengan kebebasan dalam arti yang sesunguhnya. Yang menjadi permasalahannya adalah masih banyak kita melihat upaya pengekangan dimanamana, khususnya dalam pendidikan. Guru dan murid belum merasakan otonomi yang cukup untuk menentukan arah kebijaksanaan belajar dan mengajarnya karena masih diatur dengan regulasi yang membuat rencana, proses pelaksanaan, dan evaluasi yang dilakukan terkesan dibatasi dan mengikat. Tidak jarang, kita melihat dengan aturan jam pelajaran yang harus penuhi, membuat guru dan siswa tidak bisa fokus dalam pembelajaran. Sementara, kesejahteraan belum juga sesuai dengan tuntutan yang begitu tinggi yang dipersyaratkan oleh pihak pembuat kebijakan, misalnya harus melengkapi semua perangkat pembelajaran, membuat karya lmiah (Hendri, 2020: 1).

Strategi

manajemen peserta didik sangat dibutuhkan oleh setiap lembaga pendidikan dalam meningkatkan kualitas peserta didiknya (Firdaus \& Aslinda, 2020: 95). Dalam sebuah organisasi pendidikan dibutuhkan seorang terampil yang mampu memimpin organisasi tersebut (Abdurrahman \& Firdausi, 2019: 1).

Seharusnya pengelola pendidikan harus mengetahui urgensi dari konsep merdeka belajar, sebagaimana yang diungkapkan oleh Herwina Bahar dan Venni Herli Sundi, bahwa merdeka belajar merupakan proses pendidikan untuk menciptakan suasana-suasana pembelajaran yang menyenangkan dan menggembirakan. Merdeka belajar menuntut guru, siswa dan orang tua untuk menciptakan suasana yang menyenangkan di lingkungan mereka. Merdeka Learning mengembalikan literasi pendidikan pada khittahnya sebagai motor penggerak strategis untuk mencapai tujuan pendidikan nasional. Terwujudnya proses belajar siswa memerlukan pengembangan aktif potensi siswa, sehingga dapat terlatih dengan baik jiwa keagamaan, pengendalian diri, kepribadian, kecerdasan, dan akhlak mulia, serta kemampuan siswa untuk kembali. untuk pendidikan. Kebijakan di sekolah yang diterapkan harus ditopang oleh para guru-guru (Baharuddin at all., 2020: 1).

Guru merupakan bagian yang paling menentukan dari keseluruhan sistem pendidikan dan harus mendapat perhatian sentral, karena guru selalu dikaitkan dengan bagian manapun dari sistem pendidikan. (Alwi, 2018: 13).

Hal ni dapat membebaskan guru dalam mengajar, memberikan ruang bagi kreativitas belajar siswa, dan menciptakan suasana belajar yang menyenangkan. Literasi pendidikan selalu membangkitkan rasa ngin tahu, terjadi dialog, dan menciptakan ruang; mampu bekerjasama untuk memperoleh kepercayaan diri. Dalam proses pembelajaran bebas guru, guru dapat membiarkan siswa berpikir bebas, siswa bebas bermain, siswa bebas berimajinasi, dan siswa bebas berekspresi. Membuat strategi belajar mandiri untuk 
menjadikan kegiatan mengajar lebih menekankan pada keterampilan berpikir kritis, analisis, perbandingan, generalisasi, prediksi, dan perumusan hipotesis. Menggali pemikiran divergen siswa, siswa dapat memecahkan masalah dalam proses pembelajaran. nilah yang perlu dibangun oleh semua pihak untuk mengembalikan pendidikan ke akarnya (Bahar \& Sundi, 2020: 115).

Literasi adalah proses membaca, menulis, berbicara, mendengarkan, melihat dan berpendapat (Kuder \& Hasit, 2002: 9). Secara umum definisi literasi adalah kemampuan membaca dan menulis serta menggunakan bahasa lisan. Dalam hal ni, literasi yang penulis maksud adalah literasi yang digunakan dalam pembelajaran PA adalah literasi sains. Literasi lmu pengetahuan juga keterampilan yang penting dan dibutuhkan dalam era digital saat ni. Pentingnya literasi lmu pengetahuan dikarenakan suatu permasalahan yang berkaitan dengan pengetahuan dan teknologi. Selain tu, literasi lmu pengetahuan dapat membudidayakan masyarakat dalam membuat keputusan pribadi serta berpartisipasi dalam perumusan kebijakan publik yang nantinya akan berdampak pada kehidupan (Hernandez \& Groot, 2007:12).

Terdapat ayat Al-Qur'an yang membicarakan tentang program literasi, hal tersebut sebagaimana firman Allah dalam Al-Qur'an:

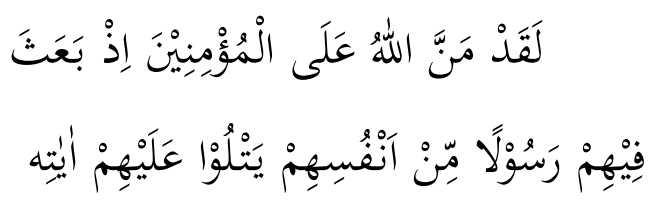

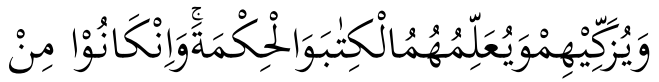

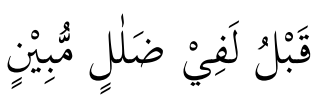

"Sungguh Allah telah memberi karunia kepada orang-orang yang beriman ketika Allah mengutus diantara mereka seorang Rasul dari golongan mereka sendiri, yang membacakan kepada mereka ayat-ayat Allah, membersibkan (jiwa) mereka, dan mengajarkan kepada mereka $A l$ kitab dan Al bikmah. dan Sesunggubnya sebelum (kedatangan Nabi) tu, mereka adalah benarbenar dalam kesesatan yang nyata". (QS. AlImran: 164).

Dalam tersebut, bahwa Rasullullah mengajarkan kepada umatnya dengan cara membaca. Bahkan Allah lah yang memrintahkan Rasulullah untuk senantiasa membaca agar mengetahui apa yang belum diketahui untuk menunjukan jalan yang terang, sehingga akan keluar dari jalan menuju kesesatan.

Berdasarkan pengamatan awal yang peneliti lakukan di SMP Negeri 12 Sijunjung bahwa, jumlah Guru PA di SMP Negeri 12 Sijunjung yang sudah tersertifikasi, ni menunjukkan bahwa Guru PA di SMP Negeri 12 Sijunjung dapat dikatakan profesional. Namun demikian, Guru PA diharapkan dapat mencerdaskan putra-putri bangsa sesuai dengan tujuan pendidikan nasional, dan diharapkan mampu merangkul peserta didik menjadi nsan yang sempurna bagi keberlangsungan hidupnya dimasa yang akan datang, sehingga yang banyak dilakukan lebih banyak kearah kegiatan pengembagan diri terkait dengan bakat peserta didik tentang lmu pengetahuan.

Untuk melakukan hal tersebut, 
tentu guru dituntut untuk memiliki kompetensi yang tinggi terhadap profesinya sebagai Guru/Pendidik. Kepala Sekolah selaku manajer pada SMP Negeri 12 Sijunjung sangat antusias dalam menyambut konsep merdeka belajar. Para guru dan pemerhati pendidikan di SMP Negeri 12 Sijunjung berharap agar konsep merdeka belajar yang akan diterapkan oleh pihak sekolah membawa perubahan positif terhadap perkembangan mutu pendidikan di sekolah (Observasi Awal, SMP Negeri 12 Sijunjung, 03 Agustus 2020).

Menurut wakil kepala sekolah bidang kurikulum bahwa dengan merebahnya berita tentang penyebaran covid 19 di Sumatera Barat, dapat berpengaruh kepada proses pembelajaran. Problematika di atas sangat berpengaruh kepada pemahaman siswa dalam mencerna pembelajaran, karena proses pembelajaran dilakukan secara daring. Maka konsep merdeka belajar yang telah dicanangkan pemerintah sangat membantu dalam menata kembali manajemen dan organisasi merdeka belajar berbasis literasi pada pembelajaran. Apalagi mata pelajara PA yang materinya lebih banyak mengarah pada praktek dan latihan. Jadi, memang sangat dibutuhkan kerja esktra dalam mengelola pembelajaran. (Wawancara, Wakil Kepala Sekolah Bidang Kurikulum, SMP Negeri 12 Sijunjung, 04 Agustus 2020).

Tujuan penelitian ni adalah untuk mendeskripsikan dan menganalisis perencanaan merdeka belajar berbasis literasi dalam pembelajaran PA di SMP Negeri12 Sijunjung serta kendala-kendala dalam perencanaan merdeka belajar berbasis literasi dalam pembelajaran PA di SMP Negeri 12 Sijunjung.

\section{METODE}

Jenis Penelitian ni menggunakan metode kualitatif. Penelitian ni termasuk dalam kategori penelitian lapangan (field research) dengan pendekatan studi kasus (case study). Penelitian ni bersifat deskriptif yang cendrung menggunakan analisis dengan pendekatan nduktif. Penelitian ni berlandaskan pada filsafat postpositivisme, kerena peneliti menggunakannya untuk meneliti pada kondisi obyek yang alamiah, yang mana, peneliti adalah sebagai ntrument kunci, pengambilan sampel sumber data peneliti lakukan secara purposive, teknik pengumpulan dengan tringgulasi, analisis data bersifat nduktif dan hasil penelitian ni lebih menekankan makna dari pada generalisasi.

Peneliti menggali nformasi dan mendapatkan data dari sumber data dengan teknik purposive di mana faktor kualitas dan prioritas nforman sangat peneliti utamakan. Pengambilan data didalam penelitian ni, dibedakan menjadi dua yaitu: sumber data primer dan sumber data sekunder (Osreni, 2020: 35).

Sumber data primer dalam penelitian ni adalah sumber data yang peneliti peroleh langsung dari SMP Negeri 12 Sijunjung mengenai perencanaan merdeka belajar berbasis literasi dalam pembelajaran PA beserta kendala-kendala yang dialami. Dalam penelitian ni, yang peneliti pilih sebagai sumber data primer adalah Guru PA SMP Negeri 12 Sijunjung tu sendiri. 
Peneliti melakukan wawancara secara mendalam dengan Guru PA tersebut yang berkaitan dengan perencanaan merdeka belajar berbasis literasi dalam pembelajaran PA di SMP Negeri 12 Sijunjung beserta kendala-kendala yang dialami.

Sumber data sekunder dalam penelitian ni adalah sumber yang tidak langsung memberikan data kepada peneliti. Tapi, data ni peneliti peroleh dari pihak lain dengan secara langsung dan tidak langsung. Sumber datasekunderni penelitguanakan untukmelengkapi dan memperkuat nformas yang telah penelitperoleh melalu observasi dan wawancara. Sumber Data sekunder yang penelitpilihdalam penelitian nadalah Kepala Sekolah SMP Negeri 12 Sijunjung, Wakil Kepala Sekolah SMP Negeri 12 Sijunjung dan dokumendokemen yang berkaitan dengan perencanaan merdeka belajar berbasis literasi dalam pembelajaran PA di SMP Negeri 12 Sijunjung beserta kendalakendala yang dialami.

Teknik pengumpulan data yang peneliti gunakan dalam penelitian ni adalah dengan cara melakukan observasi langsung ke lapangan, wawancara dengan berbagai sumber data dan menganalisissegala dokumentasi yang terkait dengan pembahasan penelitian.

Dalam hal teknik analisis data, peneliti melakukan tiga tahapan, yaitu: analisis data atau reduksi, penyajian data dan penarikan kesimpulan. Hasil dari kesimpulan ni, merupakan jawabanterhadap permasalahan yang diteliti, yaituperencanaan merdeka belajar berbasis literasi dalam pembelajaran PA di SMP Negeri 12 Sijunjung beserta kendala-kendala yang dialami.

\section{HASIL DAN PEMBAHASAN \\ Perencanaan Merdeka Belajar Berbasis Literasi pada Pembelajaran PA di SMP Negeri 12 Sijunjung \\ SMP Negeri 12 Sijunjung telah} melaksakan perencanaan dalam program merdeka belajar berbasis literasi pada pembelajaran PA dengan cara mengadakan musyawarah dengan berbagai unsur terkait. Perencanaan pembelajaran yang akan dilakukan di dalam kelas dan di luar. Perencanaan pembelajaran di dalam kelas meliputi: Pemetaan langkah-langkah ke arah tujuan yang di dalamnya tercakup unsur unsur tujuan mengajar yang diharapkan, materi atau bahan pelajaran yang akan diberikan, strategi atau metode mengajar yang akan diterapkan dan prosedur evaluasi yang dilakukan untuk menilai hasil belajar siswa.Perencanaan pembelajaran di luarkelas meliputi tahapan-tahapan dalam merealisasi

program-program literas sekolah melalui membaca, menulis dan belajar bersama yaitu dengan melakukan pembiasaan, pengembangan dan pembelajaran. Perencanaan dalam pemebelajarannya dengan melakukan gerakan literasi yang mempunya2 tujuan, yaitutujuan umum dan tujuan khusus.

Temuan penelitiandi atas sejalan dengan penelitian yang telah dilakukanoleh Nofri Hendri, Menurutnya para guru harusikut serta memikul tanggung jawab dalam perencanaan dan penyusunan pengalaman belajar yang 
terjadi di sekolah. Hal tersebut dilakukan dengan (a) menciptakan suasana yang kondusif untuk belajar melalui kerjasama dalam merencanakan program pembelajaran, (b) menemukan kebutuhan belajar, (c) merumuskan tujuan dan materi yang cocok untuk memenuhi kebutuhan belajar, (d) merancang polabelajar dalam sejumlah pengalamanibelajar untuk pesertadidik, (e) melaksanakan kegiatan belajar dengan menggunakan metode, teknik dan sarana belajar yang tepat dan (f) menilai kegiatan belajar serta mendiagnosis kembali kebutuhan belajar untuk kegiatan pembelajaran selanjutnya (Hendri, 2020: 24-25).

Perencanaan alah sejumlah kegiatanyang ditentukan sebelumnya untuk dilaksanakan pada suatu periode tertentu dalam rangka mencapai tujuan yang ditetapkan. Perencanaan menurut Bintoro Tjokroaminoto alah proses mempersiapkan kegiatan-kegiatan secara sistematis yang akan dilakukan untuk mencapai tujuan tertentu. Prajud Atmosurodirdjo, mendefinisikan perencanaan alah perhitungan dan penentuan tentang sesuatu yang akan dijalankan dalam rangka mencapai tujuan tertentu, siapa yang melakukan, bilamana, dimana, dan bagaimana cara melakukannya. Perencanaan sebagai keseluruhan proses permikiran dan penentuan secara matang menyangkut hal-hal yang akan dikerjakan di masa datangi dalam rangka mencapai tujuan yang telah ditentukan sebelumnya. Y. Diori berpendapat bahwa yang disebut perencanaani alahsuatu proses penyiapan seperangkat keputusan untuk dilaksanakan pada waktu yang akandatang, yang diarahkan untuk mencapai tujuan tertentu (Usman, 2006: 48).

Dalam proses perencanaan terhadapi program pendidikan yang akan dilaksanakan, khususnya dalam lembaga pendidikan slam, maka prinsip perencanaan harus mencerminkan terhadap nilai-nilai slami yang bersumberkan pada al-Qur'an dan alHadits. Dalami hal perencanaan ni alQur'an mengajarkan kepada manusia untuk menentukan sikapdalam proses perencanaan pendidikan, yaitu dalam alQur'an suratan-Nahl ayat 90:

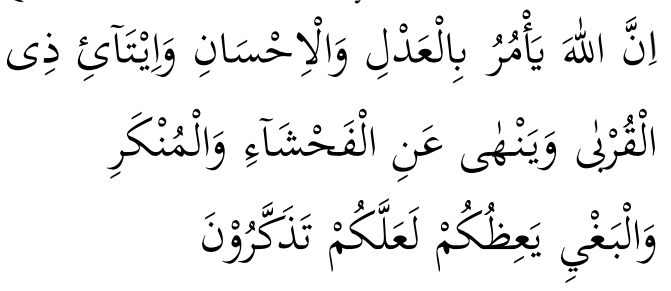

"Sesunggubnya Allab menyuruh (kamu) Berlaku adil dan berbuat kebajikan, memberi kepada kaum kerabat, dan Allah melarang dari perbuatan keji, kemungkaran dan permusuban. Dia memberi pengajaran kepadamu agar kamu dapat mengambil pelajaran."

Ayat di atas merupakan suatu hal yang sangat prinsipil yang tidak boleh ditawardalam proses perencanaan pendidikan, agar supaya tujuan yang ngini dicapaidapat tercapai dengan sempurna. Disamping tu pula ntisari ayat tersebut merupakan suatu "pembeda" antara manajemen secara umumdengan manajemen dalam perspektifIslam yang sarat dengan nilai.

Sasaran program merdeka belajar salah satunya adalah Rencana Pelaksanaan Pembelajaan (RPP). Menurut Surat Edaran Mendikbud Nomor 14 Tahun 2019, tentang Penyederhanaan RPP, yang mana sinya mencangkupi: (1) penyusunan RPP dilakukan dengan prinsip efisien, efektif, dan berorientasi pada peserta didik (2) Dari 13 komponen yang adadalam 
RPP yang mana telah tertuangi dalam Permendikbud Nomor 22 Tahun 2016, yang menjadi komponen inti adalah tujuan pembelajaran, langkah-langkah pembelajaran, dan penilaian pembelajaran (assesment) yang wajib dilaksanakan oleh guru, sedangkan sisanya hanya sebagai pelengkap; dan (3) Sekolah, Kelompok Guru Mata Pelajaran di sekolah, Musyawarah Guru Mata Pelajaran yang disingkat dengan (MGMP) dan individu guru dapat dengan bebas dalam memilih, membuat, menggunakan, dan mengembangkan format dalam RPP secara mandiri untuk sebesar-besarnya keberhasilan belajar siswa. RPP yang telahdibuat dapat digunakan serta dapat disesuaikan dengan ketentuan sebagaaimana maksud pada angka 1, 2, dan 3 .

Bila dicermati dari keseluruhan isi surat edaran mendikbud tersebut, dapatdimaknai bahwa penyusunannya lebih disederhanakan dengan memangkas beberapa komponen. Guru diberikan keleluasaan dalam proses pembelajaran untuk memilih, membuat, menggunakan, dan mengembangkan format RPP, sebab gurulah yang mengetahui kebutuhan siswai didiknya dan kebutuhan khusus yang diperlukan oleh siswa di daerahnya, karena karakter dan kebutuhan siswa di masing-masing daerahbisa berbeda. Untuk penulisan RPP-nyasupaya lebih efisiensi dan efektif, cukup dibuat ringkas bisa dalami satu halaman, sehingga guru tidak terbebani oleh masalah administrasi yang dapat menyusahkan. Diharapkan melalui kebebasan menyusun RPP kepada guru, siswa akan lebih banyak berinteraksi secara aktif, dinamis, dengan model pembelajaran yang tidak baku.

Kendala-kendala dalam Perencanaan

\section{Merdeka Belajar Berbasis Literasi dalam Pembelajaran PA di SMP Negeri 12 Sijunjung}

Terdapat beberapa kendalakendala tersebut terdiri dari 3 kendala yaitu: 1). minimnya Sumber Daya Manusia yang dapat memahami program literasi dengan baik dan benar, 2). waktu pelaksanaan kegiatan literasi di sekolah dan 3). perpustakaan sekolah hanya terbatas pada perpustakaan sekolah, dan koleksi perpustakaanya hanya menyediakan buku sekolah, sedikit sekali buku tambahan lain.

Temuan penelitian di atas sejalan dengan penelitian yang telah dilakukan oleh Dewi Nirmala Sari dan Yuliyati, bahwa, mambatan berbahasayang dialami anak tunarungudapat dioptimalkan melalui Gerakan Literasi Sekolah dengan mengembangkan keterampilan berbahasa yang meliputi keterampilan menyimak,berbicara, membaca dan menulis. Tujuan penelitianni untuk mendeskripsikan implementasi Gerakani Literasi Sekolah, faktor pendukung, faktor penghambat, serta mengatasifaktor penghambat dalam mplementas Gerakan Literasi Sekolahi bagisiswa tunarungu di SDLB-B Karya Mulia 1 Surabaya.

Penelitian ini menggunakan metode deskriptif dengan pendekatan kualitatif melalui teknik pengumpulan data yaitu wawancara, observasi, dan dokumentasi. Analisis data kualitatif model analisis Miles \& Huberman dengan menggunakan triangulasi untuk kesahihan instrumen dan data. Hasil penelitian menunjukkan, di SDLB-B Karya Mulia 1 Surabaya sudah melaksanakan implementasi Gerakan Literasi Sekolah pada tahapan pembiasaan dengan kegiatan 15-30 menit membacakan buku non pelajaran sebelum pembelajaran dimulai setiap hari sesuai jadwal kegiatan sekolah. Guru 
sudah melaksanakan aktivitas pembelajaran yang dilakukan dalam Gerakan Literasi Sekolah dengan baik. Faktor pendukung dalam implementasi gerakani literasi sekolahni adalah dukungan dari orang tua siswa, antusias siswa dalam membaca, serta antusias dan kreativitas guru. Faktor penghambatnya, belum tersedia sarana dan prasarana yang memadai, belum terdapat perpustakaan sekolah khusus di SDLB-B Karya Mulia 1 Surabaya, dan ketersediaan koleksi buku yang kurang. Sekolah dapat mengatasi faktor penghambat dalam mplementasigerakan literasi sekolah bagisiswa tunarungu di SDLB-B Karya Mulia 1 Surabaya, yaitu dengan adanya bantuan sumbangan koleksi buku bercerita bergambar dari pihak orang tua siswa danpara donator (Sar \& Yuliyati, 2018: 2).

Terdapat beberapa faktor yang sangat berpengaruh dalam pelaksanaan literasi di sekolah. Faktor utama pendukung pelaksanaan literasi sekolah adalah adanya kuatnya payung hukum terhadap pelaksanaan literasi disekolah. Kita patut berlega hati bahwa pemerintah dengan sangat legawa menyikapi dengan arif dan bijaksana terhadap hasil penelitian dari berbagai lembaga penelitian yang menyatakan bahwa minat baca peserta didikkita masih rendah. Sikap legawa pemerintah dibuktikan dengan dikeluarkannya Peraturan Pemerintah Nomori 23 Tahun 2015 tentang Penumbuhan Budi Pekerti. Salah satu karakter yang harus ditumbuhkan menurut peraturanni terdapat dalam bagianpengantar butir $\mathrm{f}$, yaitu "penghargaan terhadap keunikan potensipeserta didik gemar membaca dani mengembangkan minat yang sesuaidengan potensi bakatnya untuk memperluas cakrawala kehidupan di dalam mengembangkan dirinya sendiri. Nilani diambil dari nilai kebangsaan dan kemanusiaan yang berakar pada Pancasila".

Faktorke dua adalah dukungan penuhdari pemerintah terhadap pelaksanaan Gerakan literasi sekolah. Ada pepatah mengatakan "Jer basuki mawa bea", artinya semua kegiatan tidak terlepasdari urusan keuangan atau pendanaan. Dalam halni, dukungannyata pemerintah terhadap pelaksanaan kegiatan literasi adalah adanya pemberian dana BOS. Sebagian dana BOS dialokasikan untuk pengadaan sarana dan prasarana pelaksanaan literasi di setiap satuan pendidikan terutama pendidikan dasar dan menengah. Saran adan prasarana tersebut meliputi pengadaan buku-buku, pendanaan kepanitiaan, dan penciptaan ruang-ruang yang mendukung peserta didik melakukan kegiatan membaca.

Faktor ketiga adalah sumber daya manusia (SDM) pengelola kegiatan Gerakan Literasi Sekolah. SDM yang dimaksud adalah semua pemangku kepentingan (stekholder) di tingkat pemerintahan, dari tingkat pemerintahan pusat, LPMP, dinas pendidikan provinsi, kabupaten/kota, dansatuan pendidikan di tingkat kota.i Ditingkat satuan pendidikan, SDM sebagai ujung tombak pelaksanaan kegiatan ini adalah kepala sekolah, pengawas, guru, dan Tim Literasi Sekolah (TLS). Semua pemangku kepentingan dan SDM di tingkat satuan pendidikani "satu hati" untuk mendukung Gerakan Literasi Sekolah.

Faktor keempat adalah dikeluarkannya Juknis pelaksanaan Gerakan Literasi Sekolah. Artinya, pemerintah dalam hal ini Kemendikbud sangat serius dan berharap Gerakan Literasi Sekolah dapatberlangsung dengan baik. Kemendikbud mengeluarkan Desain Induk Gerakan Literasi Sekolah dan Panduan Gerakan 
Literasi Sekolah di setiap satuan pendidikan.

Faktorke lima, orang tua peserta didik dan masyarakat yang tentunya mendukung penuh semua kegiatan positif untuk memajukan peserta didik. Peran orang tua dan masyarakat sangat besar demi suksesnya kegiatan ini berkaitan erat dengan fungsi pemangku kebijakan dari tingkat pusat sampai dengan tingkat satuan pendidikan. Fungsi pemangku kebijakan adalah memberikan pengarahan dan pencerahan kepada orang tua peserta didikdan masyarakat bahwa kegiatan ini sangatlah urgen untuk dilaksanakan.

Faktor keenam adalah peserta didik. Faktor ini merupakan faktor penentu.i Berdasarkan perhitungan parademographer (ahli demografi) terhadap indikator dasar kependudukan (tingkat kelahiran dan kematian), Indonesia akan menikmati bonus demografi hingga tahun 2030. Kepala Pusat Penelitian (P2) Kependudukan (2013) menyimpulkan bahwa Indonesia menikmati penduduk usia produktif dalam jumlah besar terutama kaum muda yang energik dan kreatif. Artinya, kita saat ini mempunyai kaum muda (peserta didik) dalam jumlah besar yang sangat potensial untuk dijadikan "sasaran" Gerakan Literasi Sekolah.

Disamping beberapa faktor pendukung pelaksanaan gerakan literasi diatas, terdapat beberapa faktor yang yang menjadi penghambat pelaksanaan gerakan literasi di sekolah. Faktor utama penghambat program literasi di sekolah adalah rendahnya minat baca peserta didik sebagai "sasaran program tersebut. Artinya, kita harus mencari tahu faktorfaktor penyebab rendahnya minat baca peserta didik. Kita tidak boleh menutup mata bahwa rendahnya minat baca peserta didik hanyalah dampak negatif sebagai akibat faktor internal dan eksternal dari peserta didik.

Faktor internal yang sangat mempengaruhi rendahnya minat baca peserta didik (remaja) adalah usia yang kurang menguntungkan. Usia remaja merupakan masa remaja berada dalam situasi "sulit". Perkembangan jiwa pada masa ini dipengaruhi oleh faktor pembawaan internaldan faktor eksternal yaitu pendidikandan pengalaman interaksi siswad engan lingkungan (Muhibbinsyah, 2010: 47).

Menurut Barlow melalui Muhibbinsyah (2010: 79), bahwa pendekatan teori belajar sosial terhadap proses perkembangan sosial dan moral siswa ditekankan pada pembiasaan dan peniruan. Proses pembiasaan dan peniruan ini dapat dengan mudah dilakukan oleh peserta didik fase remaja. Pada faseni (12 tahuni - 21 tahun) remaja mengalami masa yang penuh kesukaran dan persoalan bukan saja bagi remaja itu sendiri, melainkan bagi orang tua, guru, dan masyarakat sekitar. Pada faseini, individu sedang berada di persimpangan antara anak-anak dan dunia dewasa. Sehubungan dengan ni, hampir dapat dipastikan bahwa segala sesuatu yang sedang mengalami atau dalam kondisi transisi dari suatu keadaan ke keadaan lainnya selalu menimbulkan gejolak, goncangan, dan benturan yang kadangkadang berakibat buruk. Artinya, pada masa ini dibutuhkan pendekatan yang tepat untuk penanaman budaya literasi sehingga dapat membentuk generasi muda yang literat.

Faktor internal lain yang berpengaruh dalam gerakan literasi sekolah yaitu guru yang tidak literat. Sebagian pendidik (guru) belum menjadikan budaya membaca sebagai bagian atau gaya hidup. Kita memaklumi kondis ini. Banyaknya tugas selain mengajar di kelas yang harus diselesaikan 
guru sebagai akibat sertifikasi guru, membuat guru kehabisan energi untuk dua jam, satu jam, setengah jam, atau bahkan 15 menit untuk sekadar membaca buku. Hal ini adalah permasalahan yang sangat kompleks. Beban guru luar biasa padat. Akibatnya, guru pun secara sadar dan tidak sadar telah meminggirkan budaya membaca buku.

Faktor eksteral yang mampu meminggirkan kebiasaan literasi peserta didik adalah keberadaan media sosial sebagai hasil perkembangan teknologi informasi. Twitter, Facebook, Line, WhatsApp, Instagram, dan masih banyak lagi. Hal-hal merupakan ancaman serius bagi keberadaan dan fungsi buku sebagai media literasi. Media sosial dianggap ancaman dan penggempur budaya baca ketika anak muda terlalu memuja bahkan setiap detik mengintip kegiatan mereka di media sosial. Media sosial bagaikan zat aditif yang menjadi candu bagi mereka. Mereka akan mengalami keadaan "sakau" apabila kuota internet habis. Tingginya kualitas dan kuantitas kegiatan menulis dan membaca pesan dimedia sosial bukanlah prestasi yang membanggakan. Justru kegiatan inilah yang mampu meminggirkan budaya membaca di kalangan pelajar. Sangatlah berat apabila buku harus melawan status dalam media sosial.

Faktor eksternal lain yang turut berpengaruh dalam pelaksanaan GLS, yaitu suasana yang kurang mampu menciptakan budaya baca merupakan faktor lain penghambat budaya baca. Faktor suasana yang dimaksud adalah lingkungan atau kondisi sekolah yang kurang mampu membangkitkan dan merangsang keinginan peserta didik untuksegera membuka buku dan membaca. Artinya, siswa kurang terangsang inderanya untuk meminggirkan media sosial dengan kecenderungan memarjinalkan kebiasaan membaca buku. Kebiasaan membaca terpinggirkan karena "suasana" bukubuku bacaan yang tidak menarik dan tempat yang membosankan.

Dalam Islam juga terdapat ayat AlQuran yang menerangkan tentang kendala-kendala dalam proses pembelajaran. Sebagaimana firman Allah dalam Surat Al-Baqarah ayat 214, yang berbunyi:

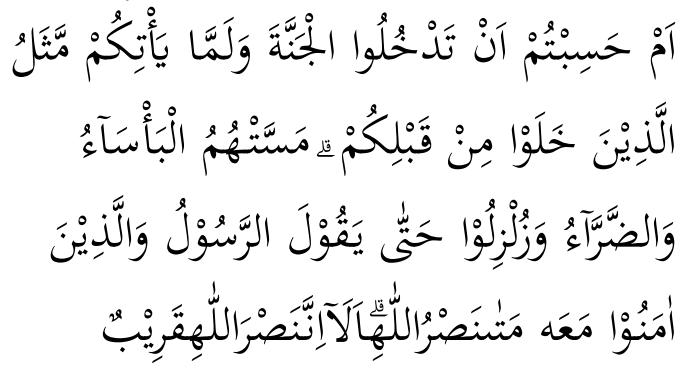

"Apakah kamu mengira bahwa kamu akan masuk syurga, Padabal belum datang kepadamu (cobaan) sebagaimana halnya orangorang terdabulu sebelum kamu? mereka ditimpa oleh malapetaka dan kesengsaraan, serta digoncangkan (dengan bermacam-macam cobaan) sehingga berkatalah Rasul dan orangorang yang beriman bersamanya: "Bilakah datangnya pertolongan Allah?" ngatlah, Sesunggubnya pertolongan Allah tu Amat dekat". (QS. Al-Baqarah: 124).

Pernyataan dalam ayat tersebut di atas dibuat sekelompok orang beriman dan utusan mereka ketika mereka tersentuh oleh kesulitan dan mereka terguncang di jalan menuju Allah. Allah berfirman kepada Rasul-Nya, kepada orang-orang beriman, dan kepada seluruh umat manusia bahwa jalan menuju Allah penuh dengan masa-masa sulit ni, termasuk juga kesulitan-kesulitan ketika mengalami kendala-kendala dalam proses pembelajaran. 


\section{KESIMPULAN REKOMENDASI \\ Kesimpulan}

Perencanaan dalam program merdeka belajar berbasis literasi pada pembelajaran PA di SMP Negeri 12 Sijunjung dengan cara mengadakan musyawarah dengan berbagai unsur terkait. Perencanaan pembelajaran yang akan dilakukan di dalam kelas dan di luar. Perencanaan pembelajaran di dalam kelas meliputi: Pemetaan langkahlangkah ke arah tujuan yang di dalamnya tercakup unsur unsur tujuan mengajar yang diharapkan, materi atau bahan pelajaran yang akan diberikan, strategi atau metode mengajar yang akan diterapkan dan prosedur evaluasi yang dilakukan untuk menilai hasil belajar siswa. Perencanaan pembelajaran di luar kelas meliputi tahapan-tahapan dalam merealisasi program-program literasi sekolah melalui membaca, menulis dan belajar bersama yaitu dengan melakukan pembiasaan, pengembangan dan pembelajaran. Perencanaan dalam pembelajarannya dengan melakukan gerakan literasi yang mempunyai 2 tujuan, yaitu tujuan umum dan tujuan khusus. Kendala-kendala Perencanaan dalam program merdeka belajar berbasis literasi pada pembelajaran PA di SMP Negeri 12 Sijunjung terdiri dari 3 kendala yaitu: 1). minimnya Sumber Daya Manusia yang dapat memahami program literasi dengan baik dan benar, 2). waktu pelaksanaan kegiatan literasi di sekolah dan 3). perpustakaan sekolah hanya terbatas pada perpustakaan sekolah, dan koleksi perpustakaanya hanya menyediakan buku sekolah, sedikit sekali buku tambahan lain.

\section{Rekomendasi}

1. Kepada jajaran Dinas Pendidikan Kabupaten Sijunjung, agar mengadakan penyuluhan atau seminar tentang pentingnya program literasi miniml pada setiap tahun ajaran baru.

2. Kepala SMP Negeri 12 Sijunjung perlu berkoordinasi dengan guru mata pelajaran PA dalam menyusun penilaian tindak lanjut, sehingga penilaian tidak hanya dilakukan hanya oleh guru mata pelajaran PA saja, tetapi juga melibatkan petugas perpustakaan.

3. Guru mata pelajaran PA SMP Negeri 12 Sijunjung diharapkan agar memahami kurikulum yang berlaku terlebih dahulu, dan mengordinasikan dengan tim literasi yang lainnya, sehingga penyusunan RPP yangsesuai dengan perkembangan peserta didik dan perkembangan kurikulum;

4. Kepala perpustakaan SMP Negeri 12 Sijunjung sebaiknya tidak hanya koordinasi dengan guru mata pelajaranIPA saja, tetapi juga dengan tim literasi yang lain, sehingga dapat mewujudkan gerakan literasi yang berwawasan literasi luas dan menyenangkan

\section{KEPUSTAKAAN ACUAN}

Abdurrahman dan Azizah Firdausi. (2019). Peran Kepemimpinan Kepala Madrasab dalam Pengendalian Mutu (Studi Kasus di MTs. Az-Zainiyah 1 Paiton, Probolinggo). Jurnal AlFikrah. Vol. 7. No. 1.

Alwi. (2018). Pengaruh Profesionalisme Guru dan Motivasi Kerja Terbadap Kinerja Guru di SMA Negeri 1 Pariangan Kabupaten Tanah Datar. Jurnal AlFikrah. Vol. 6. No. 1.

Bahar, Herwina dan Sundi, Venni Herli. (2020). Merdeka Belajar untuk Kembalikan Pendidikan pada Khittabnya. Prosiding Samasta: 
Seminar Nasional Bahasa dan Muhibbinsyah. (2010). Psikologi Sastra ndonesia.

Baharuddin, Ahmad Kausar dan Eko Prayogo. (2020). Kebijakan Kepala Madrasah dalam Meningkatkan Kualitas Peserta Didik Dhuafa. Jurnal Al-Fikrah. Vol. 8. No. 1.

Firdaus, Akmal dan Aslinda. (2020). Strategi Pengembangan Manajemen Peserta Didik dalam Meningkatkean Mutu Pendidikan di MTsN Padang Panjang. Jurnal Al-Fikrah. Vol. 8. No. 2.

Hendri, Nofri. (2020). Merdeka Belajar; Antara Retorika dan Aplikasi. Jurnal lmiah Teknologi Pendidikan. Vol. 8. No. 1.

Hernandez, J. R. dan T. Groot. (2007). Corporate Fraud: Preventive Controls Which Lower Corporate Fraud. Amsterdam Research Centre $\mathrm{n}$ Accounting.

Houtman. (2020). Mardeka Belajar Dalam Masyarakat 5.0. Universitas PGRI Palembang. Prosiding Seminar Nasional Pendidikan. 